\title{
ANALISIS PENGARUH GAYA KEPEMIMPINAN DAN LINGKUNGAN KERJA TERHADAP SEMANGAT KERJA PEGAWAI PADA DINAS LINGKUNGAN HIDUP (DLH) KOTA BIMA
}

\author{
Sirul Izzi Rahmadani \\ Sekolah Tinggi Ilmu Ekonomi Bima \\ yusufzm.stiebima@gmail.com \\ Muhammad Yusuf \\ Sekolah Tinggi Ilmu Ekonomi Bima \\ sirulizzi17.stiebima@gmail.com
}

\begin{abstract}
This study aims to determine the leadership style and work environment on the morale of employees at the Department of Environment (DLH) Kota Bima). This research was conducted at the Bima City Environmental Service Office (DLH). This research was conducted using associative research. The population used in this research is that the employees of the Bima City Environmental Service Office (DLH) are 137 employees. With a research sample of 100 State Civil Servants, with the sampling technique using purposive sampling technique. Data collection techniques used, 1, observation, 2 documentation, 3, questionnaire 4, literature study. The data analysis technique used is validity test, reliability test, classic assumption test, normality test, multicollinearity test, heteroscedasticity test, correlation coefficient test, determination coefficient test, multiple regression analysis test, hypothesis test ( $t$ test and $F$ test). The results of this study indicate that leadership style and work environment simultaneously and significantly influence employee morale at the Office of the Environment (DLH) Bima City.
\end{abstract}

Keywords: Leadership style, work environment, morale

\begin{abstract}
ABSTRAK
Penelitian ini bertujuan untuk mengetahui Gaya kepemimpinan dan Lingkungan Kerja terhadap Semangat Kerja Pegawai pada Dinas Lingkungan Hidup (DLH) Kota Bima). Penelitian ini dilakukan pada Kantor Dinas Lingkungan Hidup (DLH) Kota Bima. Penelitian ini dilakukan dengan menggunakan jenis penelitian asosiatif. Populasi yang digunakan dalam penelitian ini pegawai Kantor Dinas Lingkungan Hidup (DLH) Kota Bima sejumlah 137 pegawai. Dengan sampel penelitian 100 Aparatur Sipil Negara, dengan teknik pengambilan sampel menggunakan teknik purposive sampling. Teknik pengumpulan data yang digunakan , 1 observasi, 2 dokumentasi, 3, kuisioner 4, studi pustaka. Teknik analisa data yang digunakan, , Uji Validitas, Uji Realibilitas, Uji Asumsi Klasik, Uji Normalitas, Uji Multikolineritas, Uji Heteroskedastisitas, Uji Koefesien Korelasi, Uji Koefesien Determinasi, Uji Analisis Regresi Berganda, Uji Hipotesis (Uji t dan Uji F). Hasil penelitian ini menunjukkan bahwa Gaya kepemimpinan dan lingkungan kerja bersamaan berpengaruh secara silmutan dan signifikan terhadap semangat kerja pegawai pada kantor Dinas Lingkungan Hidup (DLH) Kota Bima.
\end{abstract}

Kata Kunci : Gaya Kepemimpinan, Lingkungan Kerja, Semangat Kerja 


\section{PENDAHULUAN}

Seiring dengan perubahan era globalisasi saat ini dan dalam kondisi masyarakat sekarang, sering kali ditemukan beberapa permasalahan yang menyebabkan banyak organisasi yang mengalami kegagalan baik yang disebabkan oleh ketidakmampuan beradaptasi dengan kemajuan teknologi maupun yang disebabkan oleh kurang baiknya hasil kerja dari sumber daya manusia yang ada pada setiap organisasi instansi pemerintahan, padahal harus diakui manusia adalah faktor penting yang turut menentukan keberhasilan organisasi.

Oleh karena itu, keberhasilan suatu organisasi sangat ditentukan oleh kegiatan pendayagunaan sumber daya manusia yaitu orang-orang yang menyediakan tenaga bakat kreativitas dan semangat bagi organisasi serta memegang peran penting dalam fungsi operasional suatu organisasi pemerintahan. Keterkaitan sumber daya manusia dengan peradaban era informasi sangatlah penting, sehingga dalam pengelolaan sumber daya manusia terdapat kecenderungan perhatian yang semakin membesar terhadap manusiasebagai faktor penentu keberhasilan suatu organisasi. Kompetisi global inilah yang mengharuskan setiap organisasi memiliki sumber daya manusia yang memiliki keunggulan. Dengan keunggulan inilah dapat diciptakan efektivitas dan efisiensi dalam proses penyelesaian pekerjaan.
Begitu pula dalam pengelolaan dinas perkantoran sangat membutuhkan tenaga kerja yang memadai secara kualitas maupun kuantitas. Pemimpin yang profesional adalah seorang pemimpin yang mampu membangkitkan semangat kerja dan menanamkan rasa percaya diri serta tanggung jawab pada bawahan untuk melaksanakan tugas-tugas penuh tanggung jawab guna mencapai produktivitas organisasi. Tentunya kepala Dinas Lingkungan Hidup (DLH) Kota Bima belum maksimal dalam mengelola pegawai, belum mampu mengarahkan bahkan mengontrol pegawai dan kurang memotivasi bawahannya, sehingga pegawai Dinas Lingkungan Hidup (DLH) Kota Bima belum mencapai tujuan organisasi yang diharapkan. Selain kepemimpinan, faktor yang mempengaruhi semangat kerja adalah lingkungan kerja. Lingkungan kerja yang baik akan menunjang pegawai menjadi senang dengan tempat kerjanya, maka akan menimbulkan semangat yang lebih baik sehingga tujuan organisasi tercapai. Lingkungan fisik suatu kantor dapat mempengaruhi semangat kerja karyawan dalam melaksanakan fungsinya. Namun dari sisi lingkungan kerja, sebagaimana yang telah penulis amati dan ditambah dari informasi yang ada, pada Dinas Lingkungan Hidup ada beberapa dari 
Analisis Pengaruh Gaya Kepemimpinan Dan Lingkungan Kerja Terhadap Semangat Kerja Pegawai Pada Dinas Lingkungan Hidup (DLH) Kota Bima

lingkungan kerja yang kurang mendukung dan harus mendapat perhatian lebih yaitu di ruangan pegawai pencahayaan yang kurang bagus, warna ruangan yang cukup kusam, serta terdapat kursi dan meja yang kurang layak digunakan sebagaimana mestinya. Seperti dalam pengamatan penulis hal ini berbeda keadaannya pada saat di ruangan pimpinan, yang mana pencahayaan sangat bagus, kursi tersusun rapi dan ruangan tersebut ber AC. Pemimpin yang profesional adalah seorangpemimpin yang mampu membangkitkan semangat kerja dan menanamkan rasa percaya diri serta tanggung jawab pada bawahan untuk melaksanakan tugas-tugas penuh tanggung jawab guna mencapai produktivitas organisasi. Tentunya kepala

\section{TELAAH LITERATUR}

\section{Gaya Kepemimpinan}

Menurut (Ardana, Komang, Mujiati, Utama, \& Mudhiarta, 2012), Gaya kepemimpinan adalah pola perilaku yang ditunjukkan oleh pemimpin dalam mempengaruhi orang lain. Pola perilaku

\section{Indikator Gaya Kepemimpinan}

Indikator-indikator kepemimpinan menurut (Kartono, 2009) terdiri dari:

a. Pembimbing

Seorang pemimpin harus mampu membimbing bawahannya agar mau bekerja serta membawa bawahannya kepada sasaran atau tujuan yang ingin
Dinas Lingkungan Hidup (DLH) Kota Bima belum maksimal dalam mengelola pegawai, belum mampu mengarahkan bahkan mengontrol pegawai dan kurang memotivasi bawahannya, sehingga pegawai Dinas Lingkungan Hidup (DLH) Kota Bima belum mencapai tujuan organisasi yang diharapkan. Melihat hal ini maka menurut penulis ada kemungkinan dampak yang ditimbulkan dari lingkungan kerja terhadap semangat kerja yang perlu untuk dikaji secara lebih mendalam. Masalah demi masalah yang terjadi dari sisi lingkungan kerja, gaya kepemimpinan serta fenomena turunnya semangat kerja pegawai, mendorong penulis untuk meneliti lebih mendalam terhadap kedua aspek tersebut dan berusaha mengukur keterkaitan antara ketiganya

tersebut bisa dipengaruhi oleh beberapa faktor seperti nilai-nilai, asumsi, persepsi, harapan, maupun sikap yang ada dalam diri pemimpin.

dituju sesuai dengan ketentuan waktu dan perencanaan

b. Komunikatif

Hubungan formal maupun informal. Suksesnya pelaksanaan tugas pemimpin itu sebagian besar ditentukan oleh kemahirannya 
menjalin komunikasi yang tepat dengan semua pihak, secara horizontal maupun secara vertikal, ke atas dan ke bawah.

c. Demokratis

Kepemimpinan demokratis berorientasi pada manusia, dan

\section{Lingkungan Kerja}

Lingkungan kerja adalah segala sesuatu yang ada disekitar para pekerja yang dapat mempengaruhi dirinya dalam menjalankan

\section{Indikator Lingkungan Kerja}

Indikator-indikator lingkungan kerja menurut (Nitisemito, 2002) terdiri dari:

- Suasana kerja

\section{Semangat Kerja}

Menurut (Tohardi, 2012)Semangat kerja adalah melakukan pekerjaan secara lebih giat, sehingga dengan demikian pekerjaan

\section{Indikator Semangat Kerja}

Terdapat beberapa indikator-indikator semangat kerja lainnya menurut (Moekijat, 2003) terdiri dari:

\section{METODOLOGI PENELITIAN}

Jenis penelitian yang akan digunakan dalam penelitian ini adalah asosiatif. Menurut (Sugiyono, 2012) penelitian asosiatif bertujuan untuk mengetahui pengaruh antara variabel yang diteliti. Dalam penelitian ini bertujuan untuk mengetahui pengaruh gaya kepemimpinan dan lingkungan kerja terhadap semangat kerja. Populasi yang digunakan yaitu memberikan bimbingan secara efisien kepada para pengikutnya. Terdapat koordinasi pekerjaan pada semua bawahan, dengan penekanan pada rasa tanggung jawab internal dan kerja sama yang baik.

pekerjaan yang dibebankan kepadanya (Alex, 2013).

- Hubungan dengan rekan kerja

- Hubungan antar bawahan dengan pimpinan

akan dapat diharapkan lebih cepat dan lebih baik.

- Kegembiraan

- Kerjasama

- Kesetiaan

seluruh pegawai Kantor Dinas Lingkungan Hidup (DLH) Kota Bima 137 Pegawai. Teknik sampling yang digunakan yaitu purposive sampling yaitu pegawai ASN 100 Pegawai. Teknik pengumpulan data adalah hal yang paling vital dalam suatu penelitian, oleh karena itu ada beberapa teknik yang digunakan dalam pengumpulan data. Cara peneliti dalam 
Analisis Pengaruh Gaya Kepemimpinan Dan Lingkungan Kerja Terhadap Semangat Kerja Pegawai Pada Dinas Lingkungan Hidup (DLH) Kota Bima

memperoleh data yang diperlukan dalam penelitian ini antara lain:

1. Observasi yaitu penelitian yang digunakan secara langsung oleh peneliti terhadap subjek penelitian yang diteliti untuk mendapatkan gambaran mengenai perusahaan sehingga data yang diperoleh dapat dipertanggungjawabkan kebenarannya.

2. Angket (Kuesioner) adalah teknik pengumpulan data yang dilakukan

\section{HASIL DAN PEMBAHASAN}

\section{Uji Validitas dan Reliabilitas}

Hasil uji validitas dalam penelitian ini diperoleh nilai Corrected Item-Total Correlation $>0,3$ sehingga dapat ditarik kesimpulan bahwa item-item kuesioner dalam penelitian ini dinyatakan valid. Hasil uji reliabiltas menunjukkan bahwa Dapat disimpulkan bahwa seluruh butir pernyataan yang berhubungan dengan seluruh variabel tersebut dapat dinyatakan dengan cara memberi seperangkat pertanyaan atau pernyataan tertulis kepada responden untuk dijawabnya.

3. Studi Pustaka merupakan pengumpulan teori yang berhubungan dengan pembahasan penulisan ini dengan mempelajari dan mengutip teori dari berbagai buku dan literatur yang terdapat di perpustakaan maupun hasil penelitian terdahulu yang berkaitan dengan penelitian ini.

reliabel. Model regresi pada penelitian ini memenuhi syarat untuk menjadi model regresi yang baik karena merupakan model regresi yang memiliki distribusi data normal, terhindar dari multikolinearitas dan autokorelasi serta tidak mengalami gejala heteroskedastisitas.

Tabel 1. Uji korelasi dan Determinasi

Model Summary ${ }^{b}$

\begin{tabular}{|l|r|r|r|r|}
\hline $\begin{array}{l}\text { Mode } \\
1\end{array}$ & $\mathrm{R}$ & $\begin{array}{c}\mathrm{R} \\
\text { Square }\end{array}$ & $\begin{array}{r}\text { Adjusted } \\
\text { R Square }\end{array}$ & $\begin{array}{r}\text { Std. Error of } \\
\text { theEstimate }\end{array}$ \\
\hline 1 &, $660^{\mathrm{a}}$ &, 436 &, 424 & 3,41620 \\
\hline
\end{tabular}

a. Predictors: (Constant), X2, X1

b. Dependent Variable: Y Sumber: Data Diolah, 2021

Berdasarkan hasil olahan data SPSS diatas diketahui bahwa besarnya hubungan antara gaya kepemimpinan dan lingkungan kerja (secara simultan) terhadap semangat kerja yang dihitung dengan koefisien korelasi adalah sebesar 0,660 berada tingkat keeratan hubungannya ada pada tingkatan yang kuat. Untuk mengetahui besarnya 
kontribusi pengaruh gaya kepemimpinan dan lingkungan kerja terhadap semangat kerja. Berdasarkan pada tabel diatas diperoleh nilai koefisien determinasi sebesar 436 atau berpengaruh sebesar
$43,6 \%$ sedangkan $\quad 56,4 \%$ lainnya dipengaruhi oleh variabel-variabel lain diluar gaya kepemimpinan dan lingkungan kerja.

Tabel 2. Uji t

\begin{tabular}{|l|r|r|r|r|r|}
\hline \multirow{2}{*}{ Model } & \multicolumn{2}{|c|}{$\begin{array}{c}\text { Unstandardized } \\
\text { Coefficients }\end{array}$} & $\begin{array}{c}\text { Standardized } \\
\text { Coefficients }\end{array}$ & \multirow{2}{*}{$\mathrm{t}$} & Sig. \\
\cline { 2 - 5 } & \multicolumn{1}{|c|}{$\mathrm{B}$} & Std. Error & Beta & & \\
\hline 1 (Constant) & 25,12 & 2,549 & & 9,855 &, 000 \\
X1 &,- 019 &, 089 &,- 016 &,- 212 &, 833 \\
X2 &, 914 &, 107 &, 663 & 8,547 &, 000 \\
\hline
\end{tabular}

a. Dependent Variable: Y

Sumber: Data, diolah,2021

Hasil dari output SPSS tersebut diatas kemudian dibandingkan dengan nilai $t$ tabel dan pada kolom Sig. dibandingkan dengan tingkat signifikansi 0,05 . t-tabel dapat dilihat pada tabel $t$ dengan derajat bebas $(\mathrm{dk})=\mathrm{N}-\mathrm{K}$ dimana $\mathrm{N}$ adalah jumlah H1: gaya kepemimpinan berpengaruh terhadap semangat kerja pada Dinas Lingkungan Hidup (DLH)Kota Bima.

Berdasarkan output spss diatas diperoleh nilai t-hitung sebesar -2,212<t-tabel 1,984 dan nilai sig 0,833>0,05 yang artinya $\mathbf{H 1}$

\section{H2: Lingkungan Kerja berpengaruh} terhadap semangat kerja pada Dinas

\section{Lingkungan Hidup (DLH)Kota Bima.}

Berdasarkan output spss diatas diperoleh nilai t-hitung sebesar 8,547 > t-tabel 1,984 sampel penelitian dan $\mathrm{K}$ adalah jumlah variabel (bebas dan terikat) maka $(\mathrm{dk})=100$ $-3=97$, pengujian dua arah pada $\alpha / 2=$ $0,05 / 2=0,025$. Sehingga diperoleh nilai ttabel sebesar 1.984 .

ditolak yaitu dapat disimpulkan bahwa tidak terdapat pengaruh gaya kepemimpinan terhadap semangat kerja pada Dinas Lingkungan Hidup (DLH) Kota Bima.

dan nilai sig $0,000<0,05$ yang artinya $\mathbf{H 2}$ diterima yaitu dapat disimpulkan bahwa tidak terdapat pengaruh lingkungan kerja terhadap semangat kerja pada Dinas Lingkungan Hidup (DLH) Kota Bima 
Tabel 3. Uji F

ANOVA ${ }^{\mathrm{a}}$

\begin{tabular}{|c|c|c|c|c|c|}
\hline Model & $\begin{array}{l}\text { Sum of } \\
\text { Squares }\end{array}$ & $\mathrm{df}$ & $\begin{array}{c}\text { Mean } \\
\text { Square }\end{array}$ & $\mathrm{F}$ & Sig. \\
\hline 1 Regression & 874,969 & 2 & 437,484 & $\begin{array}{l}37,48 \\
7\end{array}$ & , b00 \\
\hline Residual & 1132,031 & 97 & 11,670 & & \\
\hline Total & 2007,000 & 99 & & & \\
\hline
\end{tabular}

a. Dependent Variable: Y

b. Predictors: (Constant), X2, X1

Sumber : Data Diolah 2021

H3: gaya kepemimpinan dan lingkungan hidup secara simultan berpengaruh terhadap semangat kerja pada Dinas Lingkungan Hidup (DLH) Kota Bima.

Berdasarkan hasil olahan data SPSS tabel

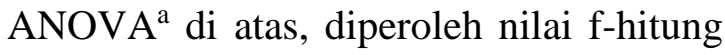
sebesar 37,487 > f-tabel 2,70 dan nilai $p$ SIMPULAN

Berdasarkan hasil analisis yang telah dilakukan, maka dapat ditarik beberapa kesimpulan sebagai berikut :

a. Gaya Kepemimpinan berpengaruh negatif dan tidak berpengaruh signifikan terhadap Semangat Kerja Pegawai Pada Kantor Dinas Lingkungan Hidup (DLH) Kota Bima.

b. Lingkungan Kerja berpengaruh positif

\section{Saran}

a. Bagi pihak Kantor Dinas Lingkungan Hidup (DLH) Kota Bima.

b. Lingkungan Kerja dalam penelitian ini terbukti mempengaruhi Semangat Kerja Pegawai. Untuk itu Kantor Dinas Lingkungan Hidup (DLH) Kota value (sig.) $0.000<\alpha=0,05$ yang artinya H3 Diterima. Hasil ini menunjukkan bahwa Gaya Kepemimpinan dan Lingkungan Kerja secara simultan berpengaruh signifikan terhadap semangat kerja pada Dinas Lingkungan Hidup (DLH) Kota Bima.

dan signifikan terhadap Semangat Kerja Pegawai Pada Kantor Dinas Lingkungan Hidup (DLH) Kota Bima.

c. Gaya Kepemimpinan dan Lingkungan Kerja tidak berpengaruh secara simultan dan signifikan terhadap Semangat Kerja Pegawai Pada Kantor Dinas Lingkungan Hidup (DLH) Kota Bima

Bima sebaiknya lebih memaksimalkan lagi Lingkungan Kerja supaya Semangat Kerja Kantor Dinas Lingkungan Hidup (DLH) Kota Bima lebih efektif dan lebih bersemangat lagi. 
c. Bagi peneliti lain yang hendak melakukan penelitian tentang Gaya Kepemimpinan dan Lingkungan Kerja hendaknya dapat mengembangkan penelitian serta

\section{DAFTAR PUSTAKA}

Alex, S. N. (2013). Manajemen Personalia, Edisi Ketiga, Cetakan Kesembilan. Jakarta: Ghalia Indonesia.

Ardana, Komang, I., Mujiati, Utama, N. W., \& Mudhiarta, I. W. (2012). Sumber Daya Manusia . Yogyakarta: Graha Ilmu.

Arikunto. (2010). Metode Riset Edisi 7. Jakarta: Rineka Cipta.

Kartono, K. (2009). Pemimpin dan Kepemimpinan. Depok: PT Raja Grafindo Persada.

Moekijat. (2003). Manajemen tenaga kerja dan hubungan kerja. Bandung: menambah kekurangan yang ada dalam penelitian ini, sehingga makin memperkaya pengetahuan tentang variabel yang dapat mempengaruhi semangat kerja

Pionir Jaya.

Nitisemito, A. S. (2002). Manajemen Personalia, Edisi Ketiga, Cetakan Kesembilan. Jakarta: Ghalia Indonesia.

Sugiyono. (2009). Metode Penelitian Bisnis. Bandung: Penerbit Alfabeta.

Sugiyono. (2012). Metode Pendekatan Penelitian Kuantitatif-Kualitatif. Bandung: Alfabeta.

Tohardi. (2012). Pemahaman Praktis Manajemen Sumber Daya Manusia. Bandung: Universitas Tanjung Pura. 